\title{
Bioavailability and cellular effects of metals on Lumbricus terrestris inhabiting volcanic soils
}

\author{
André Amaral ${ }^{\mathrm{a}, *}$, Manu Soto ${ }^{\mathrm{b}}$, Regina Cunha ${ }^{\mathrm{a}}$, \\ Ionan Marigómez ${ }^{\mathrm{b}}$, Armindo Rodrigues ${ }^{\mathrm{a}}$ \\ ${ }^{a}$ Departamento de Biologia, Universidade dos Açores, R. Mãe de Deus, APT 1422, PT-9501-855 Ponta Delgada, Portugal \\ ${ }^{\mathrm{b}}$ Biologia Zelularra eta Histologia Laborategia, Zoologia eta Biologia Zelularra Saila, Zientzi Fakultatea, \\ Euskal Herriko Unibertsitatea, 644 PK E-48080 Bilbao, Spain
}

Received 10 March 2005; accepted 23 September 2005

In earthworms, differences in the chloragogenous tissue morphometry may be related to the bioavailability of metals in soils.

\begin{abstract}
Whether the radial thickness (RT) of the chloragogenous tissue and intestinal epithelium of earthworms (Lumbricus terrestris) reflects the bioavailability of metals in soils was investigated in two areas, one with active volcanism (Furnas) and another with no volcanic activity since 3 million years ago (Santa Maria), in the Azores. Metal contents in soil samples and earthworms from the two areas were analyzed. Autometallography and measurements of the RT were performed in the chloragogenous tissue and intestinal epithelium. Earthworms from the active volcanic area demonstrated lower RT of chloragogenous tissue and intestinal epithelium as well as higher levels of bioavailable metals, especially $\mathrm{Zn}$ and $\mathrm{Cd}$. Comparison of bioavailable metal contents between both areas suggests a higher risk for uptake of potentially toxic metals in the active volcanic area than in the non-active volcanic area, which is reflected by the lower RT of the chloragogenous tissue and intestinal epithelium in the former.
\end{abstract}

(C) 2005 Elsevier Ltd. All rights reserved.

Keywords: Lumbricus terrestris; Morphological changes; Chloragogenous tissue; Metal pollution; Volcanism

\section{Introduction}

Many studies have investigated anthropogenic metal pollution but few have focused on natural inputs of metals to soils. An example of natural input is volcanic activity, which can occur through lava emissions, degassing soils, and hydrothermal sources. Volcanic rocks and gases are responsible for the presence of metals such as $\mathrm{As}, \mathrm{Hg}, \mathrm{Pb}, \mathrm{Al}$, and $\mathrm{Zn}$ in soils of volcanic origin (Ferreira and Oskarsson, 1999; Kelepertsis et al., 2001), since diffusion of acidic volcanic gases through water permeable rocks contributes to the hydrological material

\footnotetext{
* Corresponding author. Tel.: +351296650 470; fax: +351296650100. E-mail address: aamaral@notes.uac.pt (A. Amaral).
}

transfer in volcanic strata (Cruz et al., 1999). Due to the high fertility of volcanic soils, volcanic regions are typically densely inhabited, and that can make them important scenarios for the study of the effects of high levels of metals in soils.

It is widely accepted that environmental risk assessment cannot be based solely on chemical analyses, and that the measurement of the biological effects of pollutants has become very important for the assessment of environmental quality (Bayne, 1989; Gray, 1992). One approach to assessing changes in environmental quality is the use of biomarkers. Biomarkers are measurements at low levels of biological organization (molecular, cellular and tissue levels) that indicate exposure to particular compounds or elements, or the effects of such exposures (exposure biomarkers and effect or stress biomarkers, respectively). Because of their relatively prompt response, 
these biomarkers have also been proposed as "early warning" tools for biological effect measurement, in anticipation of changes at higher levels of biological organization (Cajaraville et al., 2000; McCarthy and Shugart, 1990). The biomarker approach has been widely applied in coastal areas using mussels and other mollusks as sentinels. More recently, and based on the same approach, slugs and earthworms have been proposed as sentinel species for soil quality assessment (Marigómez et al., 1998; Morgan et al., 2002).

Earthworms are burrowing detritivores that function as primary decomposers and that play an important role in the formation of soils, and mixing of their organic and inorganic fractions (Grelle and Descamps, 2000; Laskowski et al., 1998). Previous studies have shown how some of these invertebrates are able to tolerate high concentrations of metals in the soil (Langdon et al., 1999, 2001) and that the posterior alimentary canal is their main site of metal accumulation, where the chloragogenous tissue separating the absorptive epithelium from the coelom is a major metal depository (Fischer and Molnar, 1992; Morgan et al., 2002).

In addition to chloragogenous tissue, the intestinal epithelium also exhibits a great ability for metal accumulation as Morgan et al. (2002) found for another oligochaete species, Dendrodrilus rubidus.

The variation of the radial thickness of both these tissues may reflect different cellular turnover rates caused by exposure to metals and has been suggested as a biomarker of effect for metal exposure in terrestrial worms (Amaral and Rodrigues, 2005). Thus, the aim of the present study was to investigate if the radial thickness of the chloragogenous tissue and intestinal epithelium of earthworms, Lumbricus terrestris, reflects the bioavailability of metals in soils.

\section{Material and methods}

\subsection{Sampling sites}

The Azores archipelago comprises nine islands and is located in the North Atlantic Ocean at the triple junction of Eurasian, African and North American plates, characterized by a complex tectonic settlement, where seismic and volcanic phenomena are common (Nunes et al., 1993). São Miguel and Santa Maria are the two most eastern islands of this archipelago, and the latter is the oldest of all nine. Situated in São Miguel, which is the largest island $\left(757 \mathrm{~km}^{2}\right)$, Furnas is a rural parish inside a caldera complex that is considered one of the most active and dangerous volcanoes in the Azores archipelago (Guest et al., 1999). Santa Maria, which is one of the smallest islands $\left(92 \mathrm{~km}^{2}\right)$, is also rural but, in contrast, no volcanic activity took place for over 3 million years (Feraud et al., 1984).

\subsection{Soil and earthworms: collection and metal analysis}

During autumn, soil samples $(0-30 \mathrm{~cm}$ depth; $1 \mathrm{~kg})$ were collected from five sites in Furnas and four sites in Santa Maria in similar ways and processed identically for $\mathrm{pH}-\mathrm{H}_{2} \mathrm{O}$ (LNEC, 1967a), organic matter (LNEC, 1967b), claysilt percentage, moisture, and metal ( $\mathrm{Al}, \mathrm{Ca}, \mathrm{Cd}, \mathrm{Cu}, \mathrm{Fe}, \mathrm{Pb}, \mathrm{Zn}$ ) analysis. Clay-silt percentage was measured after particle-size fractionation through wet sieving, with asieve aperture lower than $63 \mu \mathrm{m}$, and separating clay-silt from sand. Moisture in soil samples was calculated by the difference between fresh and dried soil. Samples were also thoroughly mixed, air-dried and lightly crushed prior to digestion with aqua regia in preparation for determination of metal concentrations by inductive coupled plasma analysis (Actlabs, Canada).
For $\mathrm{Cd}, \mathrm{Cu}, \mathrm{Pb}$, and $\mathrm{Zn}$, samples were digested with four acids beginning with hydrofluoric acid, followed by a mixture of nitric and perchloric acids, and hydrochloric acid. Appropriate international reference materials for the metals of interest also were digested and analyzed at the same time.

By digging and hand sorting, during autumn, nine samples of clitellate L. terrestris (Oligochaeta: Lumbricidae) were collected, 20 per sample totaling 180 earthworms, from nine sites. Five samples were from five sites within Furnas and the other four were from four sites within Santa Maria. Earthworm sampling areas corresponded with the ones for soil sampling. Earthworms were transferred to the laboratory, where they were depurated of gut contents by placing them on moistened paper for $36 \mathrm{~h}$. Ten worms from each sample were dried $\left(130{ }^{\circ} \mathrm{C}\right)$, digested in concentrated nitric acid $\left(\mathrm{HNO}_{3}\right)$, and finally dissolved in $0.1 \mathrm{~N} \mathrm{HNO}_{3}$, prior to analysis of $\mathrm{Al}, \mathrm{Ca}, \mathrm{Cd}, \mathrm{Cu}, \mathrm{Fe}, \mathrm{Pb}$, and $\mathrm{Zn}$ by flame atomic absorption spectrophotometry.

\subsection{Histological processing}

The remaining 10 depurated specimens of $L$. terrestris from each site were used for light microscopy, autometallography, and morphometry purposes. From each worm, a fresh piece of tissue located posterior to the clitellum was excised and fixed, for $1 \mathrm{~h}$, in Carnoy's fixative (Martoja and Martoja-Pierson, 1970), dehydrated in alcohol, cleared in methylbenzoate (overnight), rinsed in benzene, embedded in paraffin, and sectioned at $7 \mu \mathrm{m}$ thick sections. Two sets of six sections per individual were obtained, one for autometallography and the other for morphometry.

\subsection{Autometallography}

The procedure used to demonstrate metals in the tissue sections was autometallography, which is a histochemical technique based on principles of photography (Soto et al., 1998). Paraffin sections were dewaxed in xylene, hydrated in ethanol-water mixtures and left in an oven at $37{ }^{\circ} \mathrm{C}$ until completely dried. Tissue sections were covered with a photographic emulsion (Ilford Nuclear Emulsion L4) under safety light conditions. After drying for $30 \mathrm{~min}$ in total darkness, sections were rinsed in a developer bath $(1: 5, \mathrm{~b} / \mathrm{w}$ Ultrathin Tetenal) for $15 \mathrm{~min}$, rinsed in a stop bath (1\% acetic acid) for $1 \mathrm{~min}$, and finally rinsed in a fixative bath $(1: 10, \mathrm{~b} / \mathrm{w}$ Agefix Agfa) for $10 \mathrm{~min}$ (Soto et al., 1998). Sections were mounted in Kaiser's glycerol gelatine (Merck). Metal ions were developed as black silver deposits (BSD).

\subsection{Morphometry}

Another set of sections was stained with haematoxylin and eosin (Martoja and Martoja-Pierson, 1970). To quantify the radial thickness of the chloragogenous tissue and intestinal epithelium, the first and the fifth sections of each individual were used and both were theoretically divided into four regions each, for a total of eight measurements per individual. Measurements were made by a single observer using micrometric eyepieces. For statistical analysis, it was considered the average of the eight measurements per individual, and each individual as replicate.

\subsection{Statistical analyses}

Differences in metal concentrations of soils and earthworms were examined by a one-way ANOVA and considered significant when $p \leq 0.05$. Differences determined by morphometry in the radial thickness of the earthworm chloragogenous tissue and intestinal epithelium from the nine sites were also examined by a one-way ANOVA, after $\log _{10}$ transformations of the data. Correlations and regressions between the mean metal burdens in soil and worms, and the mean radial thickness of the chloragogenous tissue and intestinal epithelium were calculated using SPSS 11.5 (SPSS Inc.). 
Table 1

Physical characteristics of the soils at both sampling areas

\begin{tabular}{llllll}
\hline Sampling areas & Soil classification & Organic matter (\% dry weight) & Moisture (\% wet weight) & Clay-silt (\% dry weight) & $\mathrm{pH}$ \\
\hline Furnas & Udivitrands & $2.51[1.15]$ & $35.59[4.70]$ & $34.00[8.87]$ & $6.58[0.52]$ \\
Santa Maria & Dystrudepts & $1.80[0.35]$ & $25.18[2.98]$ & $63.50[16.38]$ & $6.93[0.49]$ \\
\hline
\end{tabular}

Values are shown as means $[ \pm$ standard error]. Soil classification according to Soil Survey Staff (1998).

\section{Results}

The soils from the volcanically active area, Furnas, were richer in organic matter $(\mathrm{OM})$, more humid and presented a lower $\mathrm{pH}$ than the soils from Santa Maria. Also, the percentage of clay-silt in Santa Maria was almost twofold higher than in Furnas (Table 1).
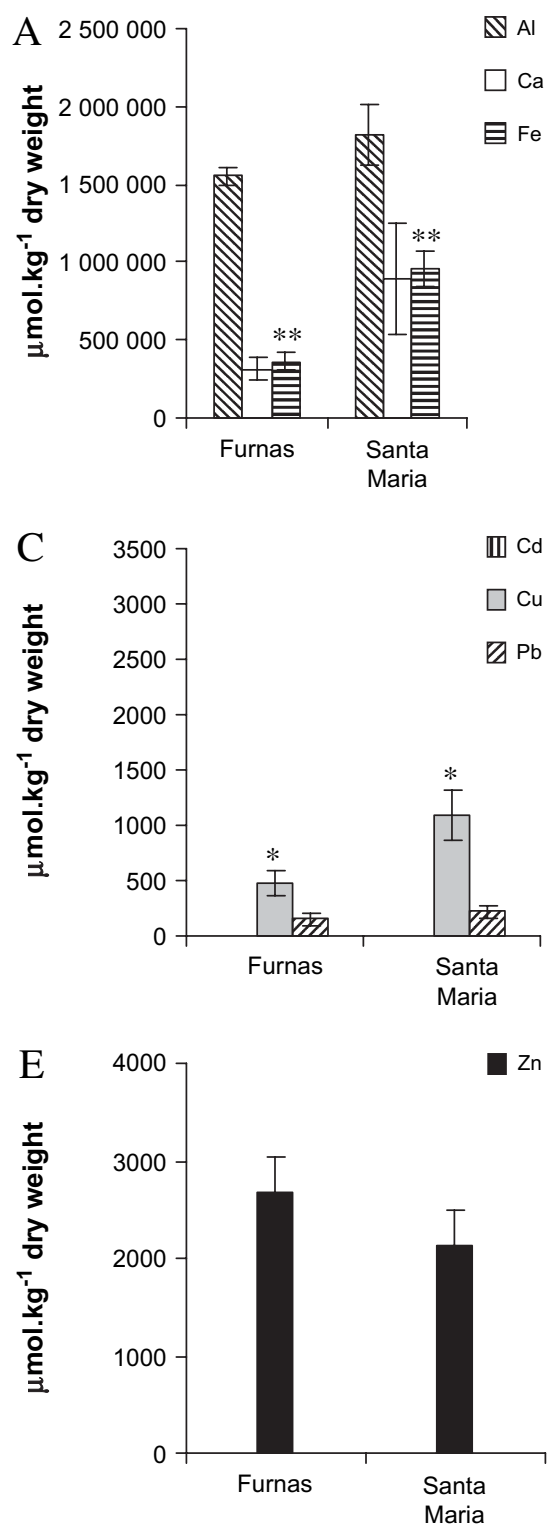

The concentrations of $\mathrm{Al}, \mathrm{Ca}, \mathrm{Cu}, \mathrm{Fe}$, and $\mathrm{Pb}$ in the soils of Santa Maria were higher than those from Furnas (Fig. 1A,C). An exception to this was the concentration of $\mathrm{Zn}$, which was higher in the latter (Fig. 1E). However, only the concentrations of $\mathrm{Cu}$ (ANOVA, $p=0.035, n=9$ ) and $\mathrm{Fe}$ (ANOVA, $p=0.002, n=9)$, almost threefold higher in Santa Maria, differed significantly between the two areas examined.
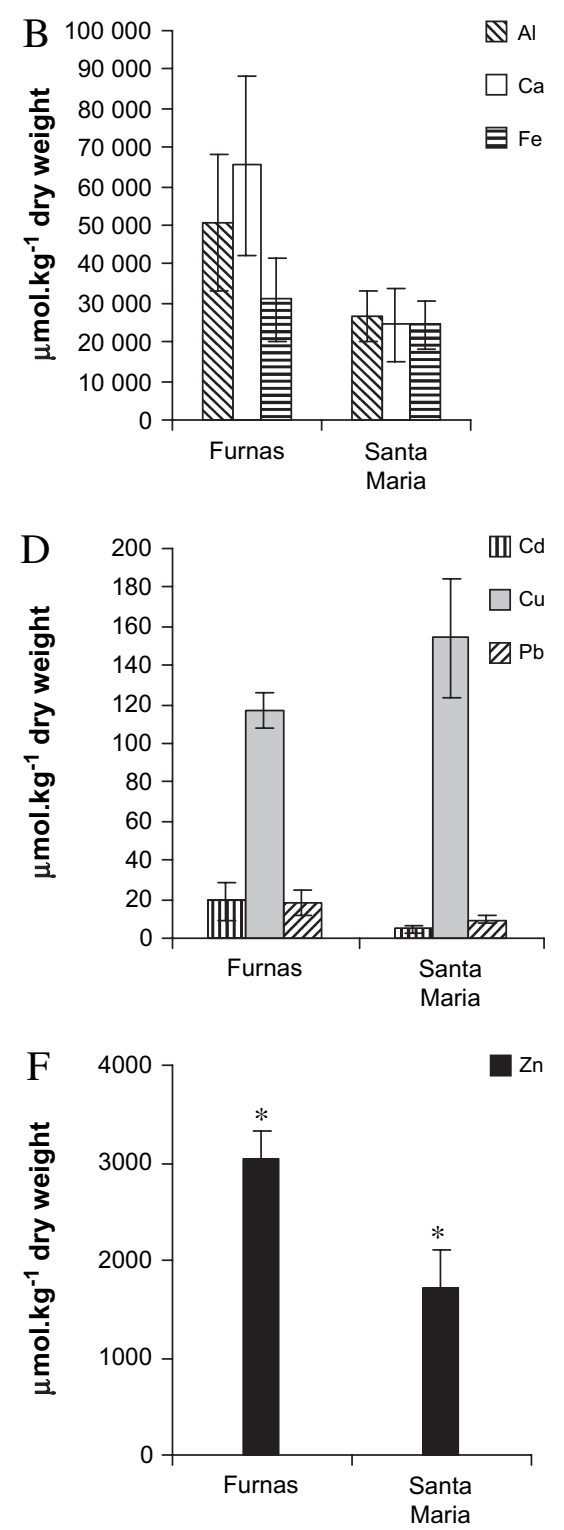

Fig. 1. Concentrations ( $\mu \mathrm{mol} \mathrm{kg}{ }^{-1}$ dry weight) $[\bar{x} \pm \mathrm{se}]$ of metals in (A,C,E) soils and in (B,D,F) L. terrestris of Furnas (active volcanism) and Santa Maria (inactive volcanism). Asterisk and double asterisks over the bars indicate significant differences at $p \leq 0.05$ and at $p \leq 0.01$, respectively. 
The concentrations of bioavailable metals, measured in the earthworms (Fig. 1B,D,F), did not correspond directly to the concentrations of metals in the soils from Furnas and Santa Maria, respectively. The metal contents in earthworms from Furnas were mostly higher than in specimens collected in Santa Maria. The only exception was $\mathrm{Cu}$ that exhibited higher levels in specimens from Santa Maria than in those from Furnas, as observed for soils from both localities (Fig. 1A-E). However, only $\mathrm{Zn}$ concentration differed significantly between the two sampled areas (ANOVA, $p=0.030, n=9$; Fig. 1F). It is interesting that the concentrations of the nutrient metal $\mathrm{Zn}$ in earthworms (bioavailable $\mathrm{Zn}$ ) from Furnas exceeded the concentrations of this metal in the corresponding soils from
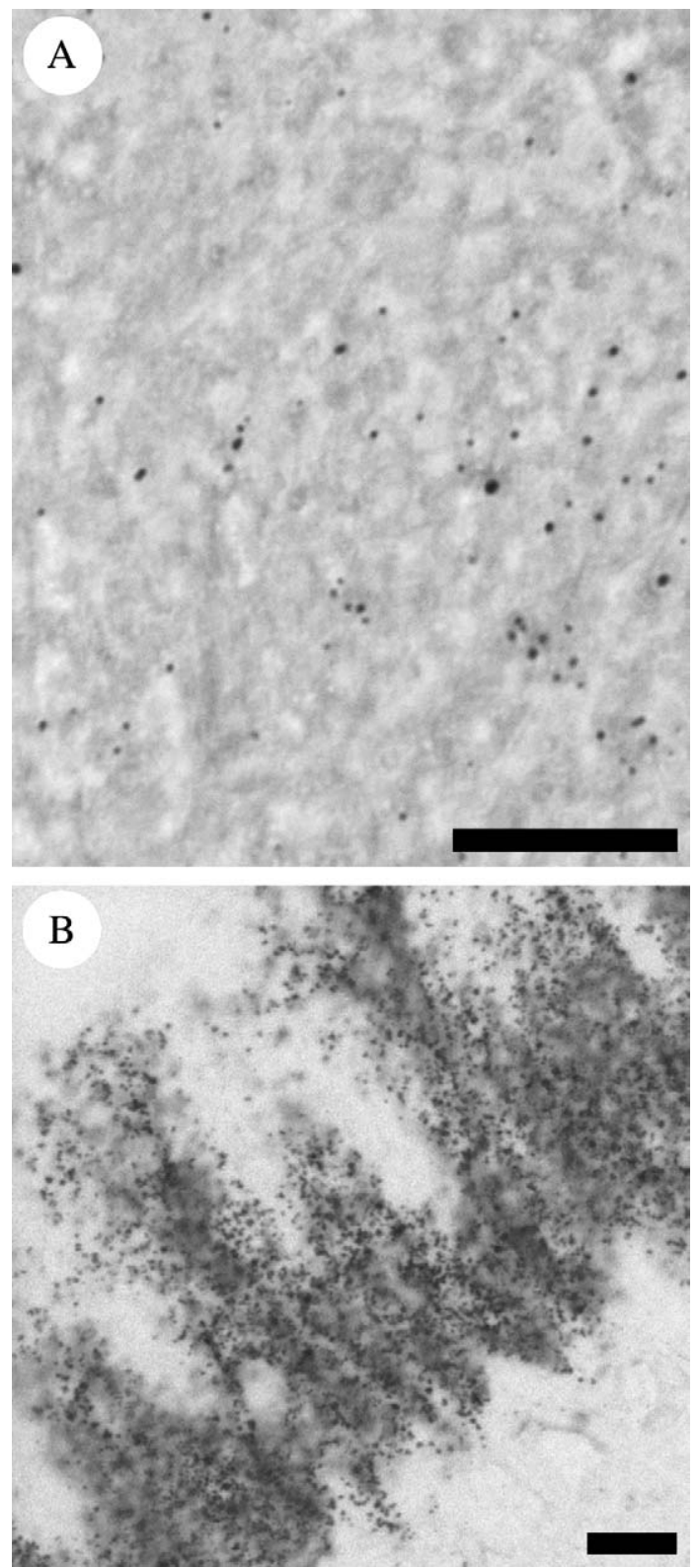

Fig. 2. (A) Chloragogenous tissue of a specimen from Santa Maria, stained with autometallography, showing few BSD. (B) Chloragogenous tissue of a specimen from Furnas, stained with autometallography, showing many BSD. Scale bars $=10 \mu \mathrm{m}$.
Furnas, while $\mathrm{Zn}$ in earthworms from Santa Maria when compared to the corresponding soils was lower (Fig. 1E,F). Cd levels in soils were below the detection limit of the spectrophotometer ( $\mathrm{DL}=4 \mu \mathrm{mol} \mathrm{kg}{ }^{-1}$ ), while bioavailable levels of $\mathrm{Cd}$ were measured in earthworms from both localities. Moreover, Cd concentration was higher in earthworms from Furnas $\left(19 \mu \mathrm{mol} \mathrm{kg}^{-1}\right)$ than in earthworms from Santa Maria (5 $\mu \mathrm{mol} \mathrm{kg}^{-1}$; Fig. 1D).

Autometallography revealed the presence of black silver deposits (BSD) mainly in the chloragogenous tissue and intestinal epithelium of specimens from all sites. However, BSD extents seem to be different between tissues and between sites (Fig. 2).

The radial thickness of the chloragogenous tissue (RTC) differed significantly between the two areas (ANOVA, $p \leq 0.001, n=90$ ), being lower in Furnas (Figs. 3 and 4). Concomitantly, the radial thickness of the intestinal epithelium (RTIE) in the earthworms of Furnas was significantly (ANOVA, $p \leq 0.001, n=90$ ) lower than those in earthworms of Santa Maria (Figs. 3 and 4). These two variables correlate significantly with each other positively (Pearson correlation $=$ $0.736, \quad p \leq 0.05 ; \quad \mathrm{RTC}=2.424 \mathrm{RTIE}-55.629)$. Moreover, a negative correlation exists between the concentrations of $\mathrm{Zn}$ in the worms and the radial thickness of the chloragogenous tissue (Pearson correlation $=-0.727, p \leq 0.05$; RTC $=$ $-0.0322 \mathrm{Zn}_{\text {worm }}+142.72$ ) and the intestine (Pearson correlation $=-0.661, p>0.05$; RTIE $\left.=-0.0089 \mathrm{Zn}_{\text {worm }}+71.054\right)$.

\section{Discussion}

The concentrations of metals in the soils of Santa Maria were not statistically different from those in the soils of Furnas, except for $\mathrm{Cu}$ and $\mathrm{Fe}$ that were in significantly higher concentrations in the soils of Santa Maria. The concentrations of $\mathrm{Zn}$ in the soils of Furnas were similar to the mean level found in US industrial/residential soils (Agency for Toxic Substances and Disease Registry, 1994) and in the vicinity of a Russian metallurgical factory (Van Straalen et al., 2001). Based on chemical analyses, earthworms did not reflect the differences in $\mathrm{Cu}$ and $\mathrm{Fe}$ concentrations in the soils. However, earthworms from Furnas and Santa Maria differed significantly in the concentrations of $\mathrm{Zn}$, the concentrations being almost twofold higher in the former. Factors such as $\mathrm{pH}$, \%clay-silt, and \%OM are recognized to influence metal bioavailability in soils (Alumaa et al., 2002; Depledge et al., 1994; Kennette et al., 2002). Therefore, the Santa Maria soils, that have considerably higher \%clay-silt than Furnas soils, have significantly higher adsorption levels of $\mathrm{Zn}$, even though the levels of $\mathrm{Zn}$ in the soils were not statistically different. Such physical characteristics of the soils may be responsible for reduced bioavailability of $\mathrm{Zn}$, and other metals, for earthworms inhabiting Santa Maria soils.

Interestingly, the levels of $\mathrm{Zn}$ in the worms of Furnas were higher when compared with the soils, and some of them were higher than the soil screening benchmark concentration for the toxicity of Zn (Efroymson et al., 1997). Thus, the earthworms 

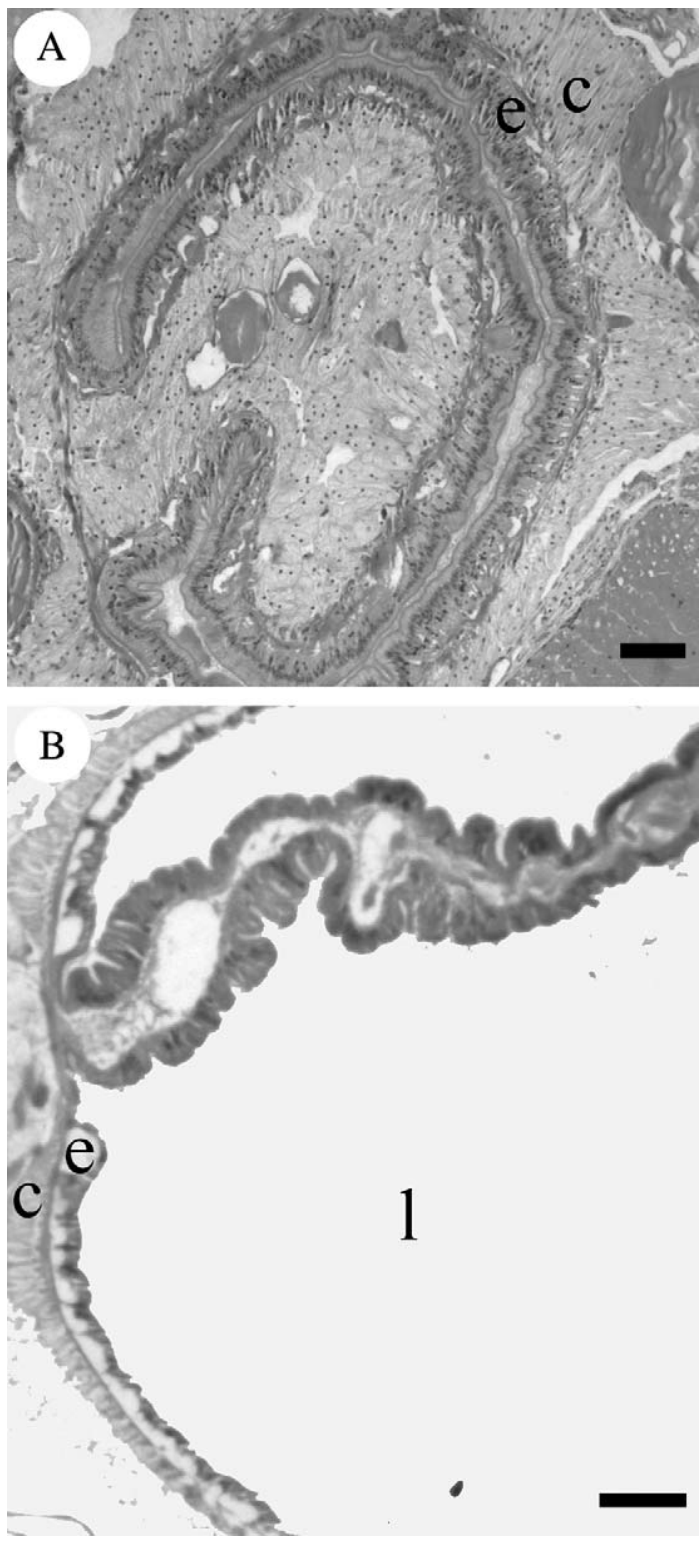

Fig. 3. (A) Section of the intestine of a specimen from Santa Maria, stained with haematoxylin and eosin, showing high chloragogenous tissue and intestinal epithelium. (B) Section of the intestine of a specimen from Furnas, stained with haematoxylin and eosin, showing reduced chloragogenous tissue and intestinal epithelium. $\mathrm{c}=$ Chloragogenous tissue; $\mathrm{e}=$ intestinal epithelium; $1=$ lumen. Scale bars $=100 \mu \mathrm{m}$.

accumulated $\mathrm{Zn}$ in higher rates than they excreted it, possibly immobilizing this metal into granules (Morgan and Morgan, 1989). This is especially relevant for $\mathrm{Cd}$ since this metal was not detectable in soil samples while measurable Cd-body burdens in earthworms in both localities suggest a net accumulation of this metal. In addition, worms from soils of Furnas exhibited higher concentration of $\mathrm{Cd}$ than worms from soils of Santa Maria, suggesting higher Cd bioavailability in the soils of Furnas.

Although BSD extents were not presently quantified, they seem to exist more in the chloragogenous tissue and intestinal epithelium of earthworms from Furnas than those of earthworms from Santa Maria. In a previous study where BSD

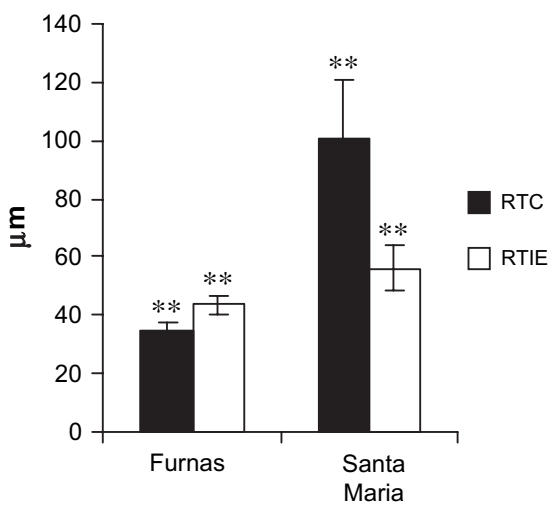

Fig. 4. Radial thickness of chloragogenous tissue (RTC) and intestinal epithelium (RTIE) $(\mu \mathrm{m})[\bar{x} \pm \mathrm{se}]$ in L. terrestris of Furnas (active volcanism) and Santa Maria (inactive volcanism). Double asterisks over the bars indicate a significant difference at $p \leq 0.01$.

extents were quantified, earthworms from Furnas exhibited a higher BSD extent than those from Santa Maria (Amaral and Rodrigues, 2005).

Significant differences in the radial thickness of the chloragogenous tissue and in the intestinal epithelium were the main biological effects observed in earthworms inhabiting both studied areas. The observed morphological differences were negatively correlated to $\mathrm{Zn}$ burdens, and may be interpreted as an adaptation of the earthworms to changes in the uptake of $\mathrm{Zn}$, on its own or in tandem with $\mathrm{Cd}$. High levels of internal $\mathrm{Zn}$, and $\mathrm{Cd}$, may have caused depletion of the studied tissues. According to Morgan et al. (2002), morphological alterations in the earthworm chloragogenous tissue are a way of handling larger quantities of metals and their elimination, by the extrusion of whole cells (Cancio et al., 1995). In agreement with this effect, it has been found that a variety of environmental organic and inorganic chemical stressors can cause changes in the chloragocytes (Fischer and Molnar, 1992; Vogel and Seifert, 1992).

Amaral and Rodrigues (2005) found higher apoptotic rates of the cells of the chloragogenous tissue and intestinal epithelium in Furnas. Since this is possibly related to higher $\mathrm{Zn}$ and Cd bioavailability it may explain the lower values of RTC and RTIE found in this volcanically active area.

\section{Conclusions}

The active volcanic area, Furnas, presents a higher bioavailability of certain metals $(\mathrm{Cd}, \mathrm{Zn})$ than the inactive volcanic area, Santa Maria, which may be stressing and forcing earthworms, and perhaps other organisms, to adapt by changing morphometric characters of some of their organs, such as the chloragogenous tissue in earthworms. Thus, the radial thickness of the chloragogenous tissue and intestinal epithelium of $L$. terrestris that reflects the bioavailability of metals in soils is herein proposed as a biomarker of effect for metal exposure, knowing, however, that more research is needed to establish this assumption. 


\section{Acknowledgements}

We thank the following for their generous assistance: $\mathrm{PhD} \mathrm{P}$. Garcia, for statistical advice, discussions and comments; and PhD J.V. Cruz, for helping with the chemical analyses. This study was financially supported by Centro de Investigação de Recursos Naturais (CIRN, University of the Azores), Direcção Regional da Ciência e Tecnologia (Government of the Azores), and the ETORTEK program from the Basque Government, through the BERRILUR project (IE03-110). André Amaral was supported by a $\mathrm{PhD}$ grant from Fundação para a Ciência e a Tecnologia (SFRH/BD/8186/2002).

\section{References}

Agency for Toxic Substances and Disease Registry, 1994. Toxicological Profile for Zinc. US Government Printing Office, Washington.

Alumaa, P., Kirso, U., Petersell, V., Steinnes, E., 2002. Sorption of toxic heavy metals to soil. International Journal of Hygiene and Environmental Health 204, 375-376.

Amaral, A., Rodrigues, A., 2005. Metal accumulation and apoptosis in the alimentary canal of Lumbricus terrestris as a metal biomarker. BioMetals 18, 199-206.

Bayne, B.L., 1989. Measuring the biological effect of pollution: the mussel watch approach. Water Science and Technology 21, 1089-1100.

Cajaraville, M.P., Bebianno, M.J., Blasco, J., Porte, C., Sarasquete, C., Viarengo, A., 2000. The use of biomarkers to assess the impact of pollution in coastal environments of the Iberian Peninsula: a practical approach. Science of the Total Environment 247, 295-311.

Cancio, I., ap Gwynn, I., Ireland, M.P., Cajaraville, M.P., 1995. The effect of sublethal lead exposure on the ultrastructure and on the distribution of acid phosphatase activity in chloragocytes of earthworms (Annelida, Oligochaeta). Histochemical Journal 27, 965-973.

Cruz, J.V., Coutinho, R.M., Rosário Carvalho, M., Oskarsson, N., Gislason, S.R., 1999. Chemistry of waters from Furnas volcano, São Miguel, Azores: fluxes of volcanic carbon dioxide and leached material. Journal of Volcanology and Geothermal Research 92, 151-167.

Depledge, M.H., Weeks, J.M., Bjerregaard, P., 1994. Heavy metals. In: Calow, P. (Ed.), Handbook of Ecotoxicology, vol. 2. Blackwell Scientific Publications, Oxford, pp. 79-105.

Efroymson, R.A., Will, M.E., Suter II, G.W., 1997. Toxicological Benchmarks for Contaminants of Potential Concern for Effects on Soil and Litter Invertebrates and Heterotrophic Process: 1997 Revision ES/ER/TM-126/R2. US Department of Energy, Washington.

Feraud, G., Schinke, H.-U., Lietz, J., Gostaud, J., Pritchard, G., Bleil, U., 1984. New K-Ar ages, chemical analyses and magnetic data of rocks from the islands of Santa Maria (Azores), Porto Santo and Madeira (Madeira archipelago) and Gran Canaria (Canary islands). Arquipélago, Ciências da Natureza 5, 213-240.

Ferreira, T., Oskarsson, N., 1999. Chemistry and isotopic composition of fumarole discharges of Furnas caldera. Journal of Volcanology and Geothermal Research 92, 169-179.

Fischer, E., Molnar, L., 1992. Environmental aspects of the chloragogenous tissue of earthworms. Soil Biology and Biochemistry 24, 1723-1727.
Gray, J.S., 1992. Biological and ecological effects of marine pollutants and their detection. Marine Pollution Bulletin 25, 48-50.

Grelle, C., Descamps, M., 2000. L'autométallographie appliquée à un modèle oligochète: Eisenia fetida typica. Avantages et limites de la technique. Bulletin de la Société Zooloqigue de France 125, 9-16.

Guest, J.E., Gaspar, J.L., Cole, P.D., Queiroz, G., Duncan, A.M., Wallenstein, N., Ferreira, T., Pacheco, J.-M., 1999. Volcanic geology of Furnas Volcano, São Miguel, Azores. Journal of Volcanology and Geothermal Research 92, 1-29.

Kelepertsis, A., Alexakis, D., Kita, I., 2001. Environmental geochemistry of soils and waters of Susaki area, Korinthos, Greece. Environmental Geochemistry and Health 23, 117-135.

Kennette, D., Hendershot, W., Tomlin, A., Sauvé, S., 2002. Uptake of trace metals by earthworm Lumbricus terrestris L. in urban contaminated soils. Applied Soil Ecology 19, 191-198.

Langdon, C.J., Piearce, T.G., Black, S., Semple, K.T., 1999. Resistance to arsenic-toxicity in a population of the earthworm Lumbricus rubellus. Soil Biology and Biochemistry 31, 1963-1967.

Langdon, C.J., Piearce, T.G., Meharg, A.A., Semple, K.T., 2001. Resistance to copper toxicity in populations of the earthworms Lumbricus rubellus and Dendrodrilus rubidus from contaminated mine wastes. Environmental Toxicology and Chemistry 20, 2336-2341.

Laskowski, R., Kramarz, P., Jepson, P., 1998. Selection of species for soil ecotoxicity testing. In: Lokke, H., Gestel, C.A.M. (Eds.), Handbook of Soil Invertebrate Toxicity Tests. John Wiley \& Sons Ltd., Chichester, pp. 21-32.

LNEC, 1967a. Solos. Determinação do pH. Documentação normativa (Especificação LNEC E203). Laboratório Nacional de Engenharia Civil.

LNEC, 1967b. Solos. Teor em Matéria Orgânica. Documentação normativa (Especificação LNEC E201). Laboratório Nacional de Engenharia Civil.

Marigómez, I., Cajaraville, M.P., Soto, M., Lekube, X., 1998. Cell-type replacement, a successful strategy of molluscs to adapt to chronic exposure to pollutants. Cuadernos de Investigación Biológica 20, 411-414.

Martoja, R., Martoja-Pierson, M., 1970. Técnicas de Histología Animal. Toray Masson S.A., Barcelona.

McCarthy, J.F., Shugart, L.R., 1990. Biological markers of environmental contamination. In: McCarthy, J.F., Shugart, L.R. (Eds.), Biomarkers of Environmental Contamination. Lewis Publishers, Boca Raton, pp. 3-14.

Morgan, A.J., Turner, M.P., Morgan, J.E., 2002. Morphological plasticity in metal-sequestering earthworm chloragocytes: morphometric electron microscopy provides a biomarker of exposure in field populations. Environmental Toxicology and Chemistry 21, 610-618.

Morgan, J.E., Morgan, A.J., 1989. Zinc sequestration by earthworm (Annelida: Oligochaeta) chloragocytes. An in vivo investigation using fully quantitative electron probe X-ray micro-analysis. Histochemistry 90, 405-411.

Nunes, J.C., Carvalho, M.R., Forjaz, V.H., 1993. Short note on São Miguel Island (Azores) tiltmeters. Açoreana 7, 633-641.

Soil Survey Staff, 1998. Keys to Soil Taxonomy, eighth ed. USDA, NRCS, Washington.

Soto, M., Quincoces, I., Marigómez, I., 1998. Autometallographical procedure for the localization of metal traces in molluscan tissues by light microscopy. Journal of Histotechnology 21, 123-127.

Van Straalen, N.M., Butovsky, R.O., Pokarzhevskii, A.D., Zaitsev, A.S., Verhoef, S.C., 2001. Metal concentrations in soil and invertebrates in the vicinity of a metallurgical factory near Tula (Russia). Pedobiologia 45, 451-466.

Vogel, J., Seifert, G., 1992. Histological changes in the chloragogen tissue of the earthworm Eisenia fetida after administration of sublethal concentrations of different fluorides. Journal of Invertebrate Pathology 60, 192-196. 